\title{
POTENSI GELATIN DARI BERBAGAI SUMBER DALAM MEMPERBAIKI KARAKTERISTIK MARSHMALLOW: REVIEW
}

\author{
Rafida Cahyaningrum, Kesya Khansa Safira, Gina Nazilah Lutfiyah, Sarah Izdihar Zahra, Aza \\ Aisyah Rahasticha, Nur Aini.
}

Program Studi Teknologi Pangan, Jurusan Pertanian, Universitas Jendral Soedirman

Jalan Dr. Soeparno, Purwokerto, 53123, Indonesia

Email: nur.aini@unsoed.ac.id

\begin{abstract}
Abstrak
Marshmallow merupakan jenis makanan ringan yaitu sejenis permen lunak. Salah satu bahan yang diperlukan dalam pembuatan marshmallow adalah bahan pembentuk gel. Salah satu bahan pembentuk gel yang biasa digunakan dalam pembuatan marshmallow adalah gelatin. Gelatin termasuk dalam hidrokoloid yang memiliki sifat dapat kembali ke keadaan semula dari bentuk sol menjadi gel atau gel menjadi sol. Artikel ini bertujuan membahas potensi penggunaan gelatin dari berbagai sumber dalam memperbaiki karakteristik marshmallow. Gelatin dapat memperbaiki karakteristik marshmallow, yang tergantung pada sumber serta proporsi gelatin yang ditambahkan. Gelatin dari kulit ikan berpotensi dalam memperbaiki tekstur marshmallow. Setiap ikan memiliki pengaruh yang berbeda, tergantung kepada jenis ikan nya, karena kolagen yang dikandung pada setiap spesies ikan berbeda-beda. Semakin tinggi viskositas gelatin dan kekuatan gel, maka kekuatan gel pada marshmallow semakin tinggi.
\end{abstract}

Kata Kunci: marshmallow, gelatin, gelling agent, karakteristik.

\begin{abstract}
Marshmallow is a type of snack that is a kind of soft candy. One of the ingredients needed in making marshmallows is a gelling agent. One of the gelling materials commonly used in the manufacture of marshmallows is gelatin. Gelatin is a hydrocolloid which has the property of being able to return to its original state from a sol to a gel or vice versa. This article aims to discuss the potential use of gelatin from various sources in improving the characteristics of marshmallows. Gelatin can improve the characteristics of marshmallows, which depends on the source and the proportion of gelatin added. Gelatin from fish skin has the potential to improve the texture of marshmallows. Each fish has a different effect, depending on the type of fish, because the collagen contained in each fish species is different. The higher the gelatin viscosity and gel strength, the higher the marshmallow gel strength.
\end{abstract}

Keywords: marshmallow, gelatin, gelling agent, characteristics Received: May 30, 2021 ; Accepted: July 8, 2021; Publish online: July 31, 2021

\section{Pendahuluan}

Marshmallow termasuk makanan ringan yang memiliki bentuk permen lunak (soft candy). Marshmallow dibuat dari putih telur, gula, gelling agent, pewarna dan perasa serta komposisi udara sangat tinggi (Aini \& Hariyadi, 2018). Dengan komposisi bahan-bahan tersebut maka marshmallow memiliki tekstur kenyal seperti busa, elastis, lembut dan cair di mulut pada saat dikunyah. Marshmallow termasuk ke dalam produk confectionery dengan berbagai variasi bentuk, warna, rasa dan aroma.

Permasalahan yang sering terjadi pada pembuatan marshmallow adalah teksturnya kurang lembut, kurang kenyal serta massa marshmallow ringan. Oleh karena itu pada pembuatan marshmallow perlu ditambahkan bahan yang berfungsi sebagai pembentuk gel (gelling agent). Gelling agent merupakan bahan tambahan pangan sebagai pengental dan penstabil berbagai bahan pangan misalnya permen, jeli dan dessert. Kemampuan gelling agent dalam membentuk tekstur pangan sangat menentukan fungsionalitasnya. Pada umumnya, gelling agent berupa protein atau polisakarida.

Salah satu bahan pembentuk gel yang selama ini sering digunakan adalah gelatin, walaupun selain gelatin ada beberapa bahan yang dapat digunakan sebagai pembentuk gel, misalnya pati termodifikasi (Aini \& Hariyadi, 2018). Walaupun demikian gelatin memiliki keunggulan sebagai pembentuk gel pada pembuatan 
marshmallow. Akan tetapi, dari segi kehalalan, ternyata masih banyak gelatin yang tidak halal, baik itu terkait sumber maupun proses pembuatannya (Shah \& Yusof, 2014). Oleh karena itu perlu alternatif sumber gelatin untuk menghasilkan marshmallow dengan karakteristik sesuai yang diinginkan.

\section{Peran Gelatin dalam Industri Pangan}

Gelatin merupakan salah satu bahan tambahan yang sering digunakan dalam industri pangan. Penggunaan gelatin dalam industri pangan adalah sebagai pengemulsi, penstabil, foaming agent (pembentuk busa), enkapsulan dan bahan pembentuk film.

Pada dasarnya, penggunaan bahan gelatin dalam pembuatan marshmallow memiliki peran penting dalam meningkatkan tekstur dan chewing ability. Kekenyalan dapat didefinisikan sebagai kemampuan suatu bahan yang apabila diberi gaya dan dilepaskan akan kembali ke bentuk semua (Darmajana et al., 2016). Secara spesifik gelatin yang ditambahkan dalam campuran pembuatan marshmallow akan membantu terjadinya pembentukan busa dan dapat menstabilkan busa yang terbentuk dengan cara meningkatkan viskositas dan menurunkan tegangan permukaan antara udara dengan cairan (gula), serta dapat mencegah terjadinya proses kristalisasi pada gula sehingga dapat membuat produk memiliki tektur yang lembut. Gelatin juga dapat berperan sebagai gelling agent atau pembentuk gel yang akan mengikat air yang terdapat di dalam marshmallow sehingga dapat dihasilkan tektur marshmallow yang tidak legket (Ann et al., 2012).

Gelatin memiliki kekenyalan yang lebih baik jika dibandingkan dengan gum. Jumlah gelatin yang ditambahkan akan sangat mempengaruhi karakteristik dari marshmallow (Aziza, Darmanto and Kurniasih, 2019). Seperti yang diungkapkan pada penelitian (Zulfajri, Harun and Johan, 2018), penambahan gelatin yang berlebihan dapat menyebabkan tektur menjadi keras dan apabila kurang optimum dapat menghasilkan marshmallow dengan tekstur yang terlalu lunak. sehingga banyak sedikitnya penambahan gelatin dalam pembuatan permen marshmallow harus disesuaikan dengan tingkat kekerasan produk akhir yang diinginkan.

Gelatin merupakan suatu senyawa protein yang sangat mudah untuk dicerna, yang dapat melengkapi jenis diet tertentu (Gomez-Guillén et al., 2002; Johnston-Banks, 1990). Makromolekul alami ini bersifat tembus cahaya, tidak berwarna, mudah rusak saat kering, tidak mempunyai rasa, dapat dimakan, dan juga memiliki beberapa fungsi, yaitu sebagai makanan diet, pereduksi garam, zat pengflokulasi, pengayaan protein, dan perekat (Arpi et al., 2018). Dengan banyaknya fungsi gelatin yang telah disebutkan tadi dan bersamaan dengan sifat gelatin sebagai pembentuk gel yang sangat baik membuat permintaan gelatin terus meningkat untuk aplikasi di bidang makanan, farmasi, dan fotografi (Saeed et al., 2013; Gomez-Guillén et al.,
2011). Gelatin diekstraksi dengan cara hidrolisis termal yang terkontrol kolagen dari berbagai macam hewan seperti babi, ikan dan sapi (Arpi et al., 2018). Sifat gelatin dipengaruhi oleh beberapa faktor intrinsik seperti sumber, umur hewan dan jenis kolagen (Johnston-Banks, 1990).

Kualitas gelatin tergantung dari sifat fisikokimianya, seperti viskositas, kekuatan gel, stabilitas termal (titik leleh dan pengaturan), komposisi asam amino, dan ukuran peptida. Gelatin komersial memiliki kekuatan gel mulai dari 50-200 g (Meng \& Cloutier, 2014), viskositas antara $2,0 \mathrm{cP}$ hingga $7,0 \mathrm{cP}$ (Johnston-Banks, 1990; Rafieian et al., 2015), titik pengaturan antara $31.6-31.80^{\circ} \mathrm{C}$ (Ninan et al., 2014), titik leleh antara $60.42-61.71^{\circ} \mathrm{C}$ (Suderman et al., 2018), jumlah glisin, prolin, dan arginin tinggi, serta mempunyai rantai beta dan alfa dengan berat molekul masing-masing sekitar 220kDa dan 100kDa (Nhari et al., 2012). Sifat fisik gelatin tergantung dengan sifat kimia gelatin, seperti distribusi berat molekul dan komposisi asam amino (Johnston-Banks, 1990). Misalnya, gelatin yang memiliki kandungan asam amino glisin dan prolin yang tinggi akan memiliki kekuatan gel yang tinggi (Siregar \& Suprayitno, 2019). Selain itu, semakin tinggi viskositas gelatin maka semakin tinggi asam amino (Rera \& Suprayitno, 2019).

Gelatin juga memiliki sifat fungsional yang khas yang dapat dibagi menjadi kelompok teo, yaitu berdasarkan sifat yang terikat dengan permukaan seperti fungsi koloid pelindung, pembentuk dan stabilitas emulsi dan busa, adesi, kohesi, dan kapasitas pembentukan film, serta berdasarkan sifat yang terikat dengan pembentuk gel seperti pengentalan, tektur, dan kapasitas mengikat air (Gareis \& Schrieber, 2007). Oleh karena itu, gelatin dapat diaplikasikan dan digunakan dalam industri makanan, pengemasan, farmasi, kosmetik, dan fotografi (Galus \& Kadzinski, 2015). Secara khusus, gelatin dapat digunakan untuk memberikan gelling, stabilisasi, tekstur dan emulsifikasi untuk roti, minuman, permen dan produk susu dalam industri makanan (Alfaro et al., 2014).

Menurut Gelatin Manufacturer"s of Europe (GME, 2011) gelatin dapat diekstrak dari kulit babi $(80 \%)$, kulit sapi $(15 \%)$ dan $5 \%$ sisanya berasal dari babi, tulang sapi, unggas, dan ikan. Gelatin dilihat dari sifatnya sebagai nilai tambah dapat digunakan dalam berbagai aplikasi di produk makanan, seperti sebagai penstabil tekstur, zat pembusa, zat pengemulsi, zat pengental dan juga dapat digunakan dalam berbagai produk makanan seperti es krim, produk susu, jeli, puding, minuman, dan produk daging. Gelatin komersial bervariasi dari 50-300 gram Bloom, kecuali untuk barang-barang khusus, bebas dari tambahan warna, rasa, pengawet, dan bahan tambahan kimia. Gelatin adalah makanan yang umumnya diakui sebagai makanan aman (GRAS) (GMIA, 2012). 


\section{Sumber Gelatin}

Karakter gelatin kulit ikan tergantung sumber ikannya. Menurut Aziza et al. (2019), gelatin dari kulit ikan payus berwarna kuning kecoklatan, sedangkan gelatin kulit ikan patin memiliki warna putih keabuabuan sedangkan gelatin kulit ikan cobia berwarna kuning jernih. Gelatin dari kulit ikan patin belum memenuhi standar warna karena standar warna gelatin adalah putih sampai kekuningan, Hal ini terjadi karena kulit ikan patin memiliki warna yang cerah yaitu putih dan terdapat corak berwarna hitam di bagian punggungnya yang berpengaruh terhadap warna gelatin yang dihasilkan. Perbedaan warna pada gelatin yang dihasilkan dapat dipengaruhi oleh bahan baku pembuatan gelatin. Dimana setiap jenis ikan memiliki karakteristiknya tersendiri. Lingkungan, makanan, dan umur ikan merupakan faktor yang dapat mempengaruhi karakteristik gelatin yang terbentuk.

Hasil uji pada pengujian rendemen didapatkan nilai yaitu $13,24 \%$ untuk ikan patin, $15,47 \%$ untuk ikan payus, dan $17,88 \%$ untuk ikan cobia. Setiap jenis ikan yang digunakan memiliki nilai rendemen yang berbeda. hal yang sama juga didapatkan pada penelitian yang dilakukan oleh Mufida et.al. (2020), dimana rendemen yang dihasilkan pada gelatin yang terbuat dari sisik ikan bandeng, tawes, dan kurisi mempunyai nilai yang berbeda. Perbedaan warna tersebut terjadi karena adanya faktor yaitu suhu yang digunakan dalam proses ekstraksi, lingkungan hidup ikan, jumlah kolagen dan protein yang terkandung dalam kulit ikan. Dimana setiap jenis ikan memiliki jumlah kolagen dan protein yang berbeda.

Pada pengujian kekuatan gel didapatkan hasil yaitu 380, 56 bloom untuk ikan patin; 328,00 bloom untuk ikan payus; dan 392,24 bloom untuk ikan combia. hal ini menunjukan dimana ikan cobia memiliki kekuatan gel yang paling tinggi diantara yang lainnya dan setiap jenis ikan yang digunakan memiliki kekuatan gel yang berbeda-beda. Hal terjadi karena spesies, habitat, dan jumlah kandungan kolagen pada jenis ikan yang berbeda dapat mempengaruhi kualitas gel yang dihasilkan. Pada pengujian viskositas didapatkan hasil yaitu 2,05 cP untuk ikan patin; 3,18 cP untuk ikan payus; dan 5,63 cP untuk ikan cobia. Hasil tersebut sudah sesuai dengan standar GMIA (2012), standar nilai viskositas antara 1,5-7,5 cP. Hasil tersebut juga menunjukan bahwa ikan cobia memiliki nilai viskositas tertinggi. Dan nilai yang dihasilkan setiap jenis ikan berbeda-beda. Perbedaan ini terjadi karena adanya pengaruh kolagen yang membentuk rantai asam amino yang panjang sehingga akan mempengaruhi viskositasnya.

Pada penelitian pembuatan gelatin dari kulit ikan oleh Rafael et al. (2021). mengungkapkan bahwa gelatin ikan bandeng memiliki karakteristik yang tidak sama dengan gelatin komersial yang terbuat dari sapi dan babi. Dimana gelatin ikan memiliki nilai pada uji kekuatan gel lebih kecil (505 bloom) dibandingkan dengan gelatin sapi dan babi (648 bloom). Hal ini dapat menyebabkan terjadi keterbatasan penggunaannya. Agar gelatin yang dihasilkan mempunyai kualitas yang baik maka karakteristik ini dapat diubah menggunakan kondisi ekstraksi atau metode pretreatment. Warna yang dihasilkan gelatin yang terbuat dari ikan yaitu berwarna putih kristal dan gelatin dari sapi berwarna putih pucat. pH yang dihasilkan oleh gelatin yang terbuat dari ikan lebih kecil yaitu sebesar 5,25 dibandingkan dengan gelatin dari sapi yaitu sebesar 5,68 dan gelatin babi sebesar 7,5. Sehingga gelatin yang terbuat dari kulit ikan dapat dijadikan alternatif yang tepat sebagai pengganti gelatin non halal yang terbuat dari babi. Dimana penggunaan ikan merupakan salah satu bahan pangan yang halal dan dapat diterima oleh seluruh agama dan budaya. Tak hanya itu saja penggunaan sisik ikan juga sebagai upaya untuk menekan jumlah limbah sisik ikan yang dihasilkan.

Santoso et. al, (2019). menyatakan bahwa penggunaan kulit kerbau sebagai bahan baku pembuatan gelatin dapat menjadi alternatif gelatin halal untuk mengganti gelatin komersial yang terbuat dari babi. Dimana nilai rendemen gelatin kulit kerbau lebih tinggi dari gelatin ikan dan sapi yaitu sebesar $25-30,2 \%$, hal tersebut terjadi karena kulit kerbau mengandung kolagen yang terhidrolisis yang tinggi dibandingkan yang lainnya. $\mathrm{pH}$ yang dihasilkan oleh gelatin kulit kerbau yaitu 5,81 sedangkan gelatin komersial sebesar 5,18. Akan tetapi gelatin kulit kerbau memiliki viskositas yang sangat tinggi yaitu 23,02 cP. Hal ini dapat terjadi karena kulit kerbau memiliki massa molekul yang lebih tinggi.

\section{Pembuatan Marshmallow}

Marshmallow dibuat dengan cara memanaskan gelatin dan air pada suhu $60^{\circ} \mathrm{C}$ selama 7 menit. Kemudian dilakukan pemanasan sukrosa dan sirup sukrosa pada suhu $80^{\circ} \mathrm{C}$ selama 7 menit. Setelah itu, kedua bahan diaduk dengan mixer selama 15 menit sampai homogen dan mengembang, lalu ditambahkan perisa. Kemudian, adonan dituang ke wadah yang telah dilapisi gula halus dan didiamkan selama 12 jam (Du Toit, Bothma, De Wit, \& Hugo, 2016).

Proses pembuatan marshmallow dilakukan dengan mencampurkan sukrosa, sirup jagung dan air, kemudian dipanaskan pada $80^{\circ} \mathrm{C}$ selama kurang lebih 8 menit hingga semua bahan tercampur, kemudian didinginkan. Sedangkan bahan pembentuk gel dimasukkan ke dalam air dan didiamkan selama 5 menit pada temperatur $75^{\circ} \mathrm{C}$. Setelah selesai, gelatin kemudian ditambahkan dalam larutan sukrosa dan sirup jagung yang telah dingin. Setelah tercampur, bahan kemudian dikocok menggunakan mixer bosch pada kecepatan 4x selama 5 menit, lalu dicetak dengan cetakan yang telah ditaburi dengan gula halus atau tepung maizena sebelumnya. Terakhir dilakukan proses aging pada marshmallow selama 5 jam di suhu kamar sampai teksturnya menjadi kaku (Aini \& Hariyadi, 2018). Marshmallow yang telah 
terbentuk dapat dipotong sesuai kebutuhan, kemudian dilakukan dusting untuk menghindari kelengketan antar marshmallow.

Penggunaan putih telur berfungsi untuk menimbulkan buih (foaming agent) saat dikocok, serta dengan adanya protein pada putih telur dapat memberikan kestabilan dari buih yang terbentuk (Sarofa, Ulya et al., 2017). Marshmallow akan semakin kenyal teksturnya seiring dengan penambahan gelatin dan putih telur. Penambahan gelatin akan menurunkan tegangan permukaan antara pertemuan udara-cairan sehingga menimbulkan pembentukan busa yang lembut dan menyebabkan tekstur produk semakin kenyal. Sebaliknya, jumlah gelatin yang kurang dapat menyebabkan marshmallow sulit untuk dicetak. Dalam pembuatan marshmallow membentuk tekstur busa lembut (foaming). Hal ini didukung oleh Sarofa, Ulya et al. (2017), yang menyatakan bahwa bahan pembantu pada pembuatan marshmallow adalah putih telur yang berfungsi sebagai foaming dan gelling agent. Putih telur ini akan membentuk gel yang lunak dan memberi warna pada marshmallow.

Pada beberapa penelitian, pembuatan marshmallow juga divariasikan dengan beberapa bahan lain. Misalnya pada penelitian yang dilakukan (Sarofa \& Dewi Wulandari, 2019) menambahkan putih telur dan albedo kulit pisang raja yang sudah dihaluskan. Fungsi dari penambahan putih telur adalah sebagai foaming agent dalam pembuatan marshmallow serta protein dalam putih telur dapat menstabilkan buih yang terbentuk. Selain itu, kulit pisang raja juga ditambahkan karena dinilai memiliki banyak kandungan yang lengkap seperti karbohidrat, protein, lemak, Fe, P, Ca, vitamin C, vitamin B serta air (Fatemeh et al., 2012). Pada penelitian yang dilakukan (Ann et al., 2012), pada pembuatan marshmallow menggunakan penambahan ekstrak bit merah dalam pembuatannya. Penambahan bit merah berguna untuk menambahkan warna pada marshmallow sehingga dapat lebih diminati konsumen, khususnya anak-anak. Selain itu, bit merah sebagai pewarna alami dinilai lebih aman digunakan sebagai pewarna dibandingkan dengan pewarna sintetik. Berbeda dengan penelitian yang dilakukan oleh (Zulfajri, Harun and Johan, 2018) yang menggunakan penambahan sari buah naga merah dalam prosesnya. Buah naga merah mengandung kadar air tinggi dan kaya akan vitamin $\mathrm{A}$, vitamin $\mathrm{C}$, vitamin $\mathrm{E}$, protein dan serat serta sumber mineral seperti fosfor, magnesium dan kalsium. Menurut Laurencia \& Tjandra (2018), manfaat dari buah naga merah yaitu dapat menetralkan racun dalam tubuh, menetralisir radikal bebas, serta membantu proses metabolisme.

\section{Marshmallow dengan Penambahan Gelatin dari Kulit Ikan}

Menurut Aziza et al. (2019), kulit ikan dapat digunakan sebagai komponen utama dalam pembuatan gelatin karena potensinya sebagai sumber kolagen yang sesuai dengan karakteristik yang dibutuhkan oleh fungsi yang akan dihasilkan dari adanya gelatin. Pemilihan ikan menjadi salah satu faktor penting yang harus diperhatikan, karena perbedaan jenis atau spesies ikan dapat menyebabkan adanya perbedaan karakteristik pada marshmallow yang dihasilkan, yang meliputi kekuatan gel serta sifat sensoris seperti bau, aroma, dan rasa. Hal tersebut sejalan dengan hasil penelitian yang menunjukkan bahwa, nilai rata-rata kekuatan gel marshmallow dengan gelatin ikan patin adalah sebesar 1055,01 g.cm, sedangkan kekuatan gel pada gelatin ikan payus adalah sebesar 1379,69 g.cm, serta kekuatan gel marshmallow dengan gelatin ikan cobia yaitu sebesar 1564,19 g.cm. Besar kecilnya nilai kekuatan gel pada marshmallow dipengaruhi oleh viskositas dan kekuatan gel gelatinnya, dimana semakin besar tingkat viskositas dan kekuatan gel gelatinnya maka semakin meningkat pula kekuatan gel marshmallow yang dihasilkan. Hal ini disebabkan oleh adanya pembentukan laju pelelehan dan peningkatan pembentukan gel yang lebih banyak pada viskositas gelatin yang semakin tinggi pula. Selain itu, terbentuknya gel dengan karakteristik kekuatan yang baik juga dipengaruhi dengan kandungan airnya, dimana dengan ketersediaan kadar air yang semakin rendah pada bahan karena diikat oleh asam amino jenis glisin maka semakin maksimal kekuatan gel yang dihasilkan.

Karakteristik yang ditinjau dari kekuatan gel ini juga mempengaruhi terhadap elastisitas marshmallow yang dihasilkan, dimana dengan kekuatan gel yang baik cenderung akan menghasilkan tingkat elastisitas yang baik pula. Hal ini dibuktikan dalam penelitian Aziza et al. (2019), bahwa penggunaan gelatin ikan cobia yang memiliki nilai kekuatan gel paling besar juga menghasilkan elastisitas yang paling baik dengan nilai 95,16 mm. Serta dengan semakin menurunnya kekuatan gel pada penggunaan gelatin ikan payus dan ikan patin, juga menunjukkan adanya penurunan nilai elastisitas, dimana marshmallow dengan gelatin ikan payus memiliki elastisitas sebesar $83,72 \mathrm{~mm}$, dan elastisitas terendah yaitu pada penggunaan gelatin ikan patin dengan nilai yang dihasilkan yaitu sebesar 76,63 mm.

Adanya perbedaan karakteristik marshmallow yang dihasilkan akibat variasi jenis ikan sebagai bahan pembuatan gelatin juga diungkapkan dalam penelitian yang dilakukan oleh Rafael et al. (2021), yang membuktikan bahwa kekuatan gel marshmallow dengan penggunaan gelatin ikan bandeng adalah sebesar 505,17 gram, sedangkan dengan penggunaan jenis ikan yang 
lain yaitu ikan nila hitam menghasilkan kekuatan gel yang lebih baik yaitu sebesar 850 gram, serta kekuatan gel yang paling rendah dihasilkan dengan penambahan gelatin dari ikan nila yaitu sebesar 2,83 gram. Penggunaan sisik ikan bandeng sebagai komponen baku dalam pembuatan gelatin menghasilkan marshmallow dengan karakteristik yang cenderung baik yang dibuktikan dengan adanya hasil penilaian oleh panelis. Karakteristik tersebut meliputi warna yang memiliki nilai sebesar 12,42, aroma dengan nilai sebesar 11,76, tekstur dengan nilai sebesar 11,78 , rasa dengan nilai sebesar 12,02, kemanisan dengan nilai sebesar 11,78, dan after taste dengan nilai sebesar 11,57. Nilai tersebut menunjukkan bahwa karakteristik marshmallow yang dihasilkan berada dalam rentang nilai yang cukup disukai sampai sangat disukai oleh panelis.

Selain ditinjau dari karakteristik sensori, penggunaan gelatin dengan variasi jenis ikan juga memiliki pengaruh terhadap karakteristik kimiawinya. Hal ini sesuai dengan penelitian yang dilakukan oleh Mufida et al. (2020), bahwa gelatin yang dibuat dari komponen utama ikan tawes, ikan bandeng, dan ikan kurisi, menghasilkan karakteristik marshmallow yang sedikit berbeda serta memberikan pengaruh dalam perbaikan karakteristik baik sensoris maupun kimiawinya. Penggunaan gelatin ikan berpengaruh terhadap hasil kadar air marshmallow, dimana kadar air dalam marshmallow dengan gelatin ikan tawes sebesar 16,70, dengan gelatin ikan bandeng sebesar 18,06, serta dengan gelatin ikan kurisi sebesar 17,00. Hasil kadar air tersebut menunjukkan nilai yang sesuai dengan standar produksi marshmallow dan penambahan gelatin akan memaksimalkan pengikatan air dalam bahan sehingga menghasilkan karakteristik produk yang baik. Penambahan gelatin dari bahan tertentu juga mempengaruhi ketersediaan kadar abu dalam produk marshmallow, hal ini disebabkan oleh adanya perbedaan kandungan mineral pada jenis-jenis atau spesies dari ikan yang digunakan. Berdasarkan data penelitian, kadar abu dalam marshmallow dengan gelatin ikan tawes sebesar 0,93, dengan gelatin ikan bandeng sebesar 1,48, dan kadar abu yang paling besar pada penggunaan gelatin ikan kurisi sebesar 2,12, dimana secara keseluruhan penambahan gelatin dari bahan ikan menghasilkan perbaikan karakteristik marshmallow yang ditinjau dari nilai gizinya yaitu kadar abu atau kandungan mineral yang berbeda-beda bergantung pada spesies ikan yang digunakan.

\section{Penutup}

Ikan memiliki potensi sebagai sumber kolagen, yaitu sama dengan fungsi yang akan dihasilkan oleh kehadiran gelatin. Pada pembuatan marshmallow ikan dapat berfungsi dalam mempengaruhi karakteristik dari marshmallow, baik mengenai kekuatan gel maupun sifat sensoris bau, warna dan aroma. Setiap ikan memiliki pengaruh yang berbeda, tergantung kepada jenis ikan nya, karena kolagen yang dikandung pada setiap perbedaan habitat dan spesies ikan berbeda. kekuatan gel pada marshmallow dapat dipengaruhi pula dengan tingkat kekuatan gel dan viskositas gelatinnya. Semangkin tinggi viskositas gelatin dan kekuatan gel, maka kekuatan gel pada marshmallow yang dihasilkan juga akan semakin tinggi. Kekuatan gel yang baik cenderung akan menghasilkan tingkat elastisitas yang baik pada marshmallow.

\section{Daftar Pustaka}

1. Aini, N., \& Hariyadi, P. (2018). Utilization of Modified White Corn Starch in Producing Marshmallow Cream. Indones. J. Fundam. Appl. Chem, 3(2), 40-46.

2. Alfaro, A.T.; Balbinot, E.; Weber, C.I.; Tonial, I.B.; Machado-Lunkes, A. (2014). Fish gelatin: Characteristics, functional properties, applications and future potentials. Food Eng, 7(1), 33-44.

3. Ann, K. C., Suseno, T.I.P., \& Utomo, A.R. (2012). Pengaruh Perbedaan Konsentrasi Ekstrak Bit Merah dan Gelatin terhadap Sifat Fisikokimia dan Organoleptik Marshmallow Beet. Jurnal Teknologi Pangan dan Gizi, 11(2), 28-36

4. Artamonova, M., Piliugina, I., Samokhvalova, O., Murlykina, N., Kravchenko, O., Fomina, I., \& Grigorenko, A. (2017). Study of the properties of marshmallow with the Sudanese rose and black chokeberry dyes upon storage. EUREKA Life Science, 3, 15-23. Retrieved from http://www.eujr.eu/life/article/view/348/332

5. Arpi, N., Fahrizal, \& Novita, M. (2018). Isolation of fish skin and bone gelatin from tilapia (Oreochromis niloticus): Response surface approach. IOP Conference Series: Materials Science and Engineering, 334, 012061. https://doi.org/10.1088/1757-899X/334/1/012061

6. Aziza, I. N., Darmanto, Y. S., \& Kurniasih, R. A. (2019). Pengaruh gelatin dari kulit ikan yang berbeda terhadap karakteristik fisik dan sensori produk marshmallow. Jurnal Perikanan, 21(1), $17-23$.

https://doi.org/10.22146/jfs.42739.Pengaruh

7. Du Toit, L., Bothma, C., De Wit, M., \& Hugo, A. (2016). Replacement of gelatin with Opuntia ficus-indica mucilage in flavored pink and unflavored white marshmallows. Part 2: 
Consumer liking. JPCD, 18, 40-51. Retrieved from

http://jpacd.org/downloads/Vol18/4_JPACD18_2 016_Pag40_51_Du_Toit_et_al.pdf

8. Gareis, H.; Schrieber, R. (2007). Gelatine Handbook: Theory and Industrial Practice; Wiley-VCH Verlag $\mathrm{GmbH}$ and Co. KGaA: Weinheim, Germany.

9. Galus, S.; Kadzi 'nska, J. (2015). Food applications of emulsion-based edible films and coatings. Trends Food Sci. Technol, 45(2), 273283.

10. GME. (2011). Gelatin Manufacturers of Europe.

11. GMIA. (2012). Gelatin Handbook. Gelatin Manufacturers Institute of America.

12. Gomez-Guillén, M. C., Turnay, J., FernándezDiaz, M. D., Ulmo, N., Lizarbe, M. A., \& Montero, P. (2002). Structural and physical properties of gelatin extracted from different marine species: A comparative study. Food Hydrocolloids, $\quad$ 16(1), 25-34. https://doi.org/10.1016/S0268-005X(01)00035-2

13. Gómez-Guillén, M. C., Giménez, B., LópezCaballero, M. E., \& Montero, M. P. (2011). Functional and bioactive properties of collagen and gelatin from alternative sources: A review. Food Hydrocolloids, 25(8), 1813-1827. https://doi.org/10.1016/j.foodhyd.2011.02.007

14. Johnston-Banks, F. A. (1990). Gelatine. In P. Harris (Ed.), Food Gels (pp. 233-289). Springer Netherlands. https://doi.org/10.1007/978-94-009. 0755-3 7

15. Laurencia, E. \& Tjandra, O. (2018). Identifikasi Senyawa Kimia Ekstrak Metanol Buah Naga Merah (Hylocereus polyrhiz) dengan Kromatografi Gas. Tarumanagara Medical Journal, 1(1), 67-73

16. Meng, Y., \& Cloutier, S. (2014). Chapter 20Gelatin and Other Proteins for Microencapsulation. In A. G. Gaonkar, N. Vasisht, A. R. Khare, \& R. Sobel (Eds.), Microencapsulation in the food industry (pp. 227239). Academic Press. https://doi.org/10.1016/B978-0-12-4045682.00020-0

17. Mufida, Rahma Tika., Darmanto, Yudhomenggolo Sastro., and Suharto, Slamet. (2020) 'KARAKTERISTIK PERMEN JELLY DENGAN PENAMBAHAN GELATIN SISIK IKAN YANG BERBEDA', Jurnal Ilmu dan Teknologi Perikanan, 2(1), pp. 29-36.

18. Nhari, R. M. H. R., Ismail, A., \& Che Man, Y. B. (2012). Analytical Methods for Gelatin Differentiation from Bovine and Porcine Origins and Food Products. Journal of Food Science, 77(1), R42-R46. https://doi.org/10.1111/j.17503841.2011.02514.x

19. Ninan, G., Joseph, J., \& Aliyamveettil, Z. A.
(2014). A comparative study on the physical, chemical and functional properties of carp skin and mammalian gelatins. Journal of Food Science and Technology, 51(9), 2085-2091. https://doi.org/10.1007/s13197-012-0681-4

20. Rafael, Mark Yohance B., Rafael, Rosalie R., Landingin, Ervee P., Rafael, Ronalie B., Tayag, Geraldine G., Santos., E, John Paul., and Rafael, Mark Joseph R. (2021) 'Gelatin from Milkfish Scales for Food Application', Journal of Science and Technology, 5(1), pp. 10-23.

21. Rafieian, F., Keramat, J., \& Shahedi, M. (2015). Physicochemical properties of gelatin extracted from chicken deboner residue. LWT - Food Science and Technology, 64(2), 1370-1375. https://doi.org/10.1016/j.lwt.2015.04.050

22. Rera, D. L., \& Suprayitno, E. (2019). Gel Strength, Viscosity and Amino Acid Profile of Gelatin Extracted From Fish Skin of Lencam (Lethrinus lentjan). International Journal of Scientific and Research Publications (IJSRP), 9(4).

23. Saeed, Mohamed \& Mirghani, Mohamed \& Adam, Aishah. (2013). Fish gelatin and its applications in selected pharmaceutical aspects as alternative source to pork gelatin. Journal of Food, Agriculture and Environment. 11, 73-79.

24. Santoso, Umar., Yudi Pranoto., Yessy T Afriyanti., Sri Mulyani. (2019). The Physical and Chemical Properties of Marshmallow made from Buffalo (Bubalus bubalis) Hide Gelatin Compared to Commercial Gelatin. journal of Applied Food Technology, 6(2), 28-34.

25. Sarofa, U., Rosida., \& Wulandari, L.P.D. (2019). Karakteristik Marshmallow dari Kulit Pisang Raja (Musa textilia): Kajian Konsentrasi Gelatin dan Putih Telur. Jurnal Teknologi Pangan, 13(1), 2027

26. Shah, H., \& Yusof, F. (2014). Gelatin as an ingredient in food and pharmaceutical products: An islamic perspective. Advances in Environmental Biology, 8(3 SPEC. ISSUE), 774780.

27. Siregar, G. R. M., \& Suprayitno, E. (2019). Amino Acid Composition of Gelatin from Ephinephelus sp. Ipaper/Amino-Acid-Composition-of-Gelatinfrom-Ephinephelus-

SiregarSuprayitno/5944694b4137bb14c20e74cfc4 47d610afe70b93

28. sa, M. I. N., \& Sarbon, N. M. (2018). Characterization on the mechanical and physical properties of chicken skin gelatin films in comparison to mammalian gelatin films. Conference Series: Materials Science and Engineering, 440(1), 1-12. 
29. S.R., Fatemeh., R., Saifullah., F.M.A., Abbas., \& M.E., Azhar. (2012). Total Phenolic, Flavonoid, and Antioxidants Activity of Banana Pulp and Peel Flours: Influence of Variety and Stage of Ripeness. International Food Research Journal, 19(3), 1041-1046. 